\title{
Analysis of Mathematical Connection and Students' Self Confidence in Flat-Side Space Material
}

\author{
Muhamad Agus Jalaludin ${ }^{*}$, Winda Yunita² ${ }^{2}$ Ita Nur Indahsari ${ }^{3}$, Ratni Purwasih ${ }^{4}$
}

1,2,3,4 IKIP Siliwangi

A R T I C L E I N F O

Article history:

Received 21 May 2018

Received in revised

form

12 June 2018

Accepted 17 July 2018

Available online 21

August 2018

Keywords:

Mathematical connection

Self Confidence

\begin{abstract}
A B S T R A C T
This research is a study to analyze the ability of mathematical connections and self-confidence in the flat-side space material for junior high school students. This research used a qualitative descriptive method. The study was conducted at 47 Bandug Junior High School in 9th grade students of SMPN 47 Bandung who had studied in a flat side room. The research subjects were ninth grade $\mathrm{F}$. The data were collected in the form of a description of the test instrument and self-confidence questionnaire. The results of the study concluded: 1) the level of students' mathematical connection skills in the settlement pointed at good categories; 2) students have mastered the materials so that they could understand problems and concepts well; 3) students already have had good self-confidence.
\end{abstract}

Copyright (C) Universitas Pendidikan Ganesha. All rights reserved.

\section{Introduction}

The development of modern technology today is closely related to mathematics. Mathematics has an important role to develop the mindset and underlying the development of other sciences. Therefore, mathematics is a component of subjects that must be taught from elementary to university level. Through learning mathematics, humans are able to think rationally and argue according to the facts. This is in line with Aripin \& Purwasih (2017) that mathematics is an important part of the field of science. When viewed from the point of classification of the field of science, mathematics is included in the exact sciences which require more creative thinking than memorization. Mathematics cannot be separated from various other scientific disciplines and problems that occur in everyday life. Material in mathematics has a relationship between one concept and another concept, therefore a person's ability to connect between concepts is very necessary in solving mathematical problems.

According to Daryanto in Uno (2012: 240) mathematics is learning that emphasizes students to think logically, systematically, critically, and work together so that they are able to develop the ability to solve various everyday problems. In line with the opinion of Daryanto, Uno (2008: 129) also suggests that mathematics is a field of science that becomes a tool of thought, communication, and tools to solve various problems or practical problems, the elements of which are logic and intuition, analytical, and construction, generality, and individualism. Whereas according to Muhsetyo (2008: 26) states that mathematics learning is the process of giving learning experiences to students through a series of planned activities so that students obtain competencies about the mathematics material being studied.

Johnson and Rising as quoted in Ajay (2016) state that mathematics is a pattern of thinking, an organizing pattern, logical proof. Mathematics is a language that uses terms that are carefully defined, clear, and accurate, representations with symbols and solids, more in the form of language symbols about ideas than knowing sounds. Furthermore, according to Karso (2007: 1.4) states that "mathematics is a science that is deductive, axiomatic, formal, hierarchical, abstract, symbolic language that is dense of meaning and the like" ..

Based on the understanding of mathematics subjects so in mathematics learning at elementary school involves 2 parties, namely the teacher as facilitator and students as learners. Students still think 
that math subjects are difficult and less interesting. Mathematics is considered a difficult subject so it is less desirable (Giarti, 2014: 13-27). In mathematics learning in order to attract the interest of teacher students are required to be able to make a variety of fun learning efforts. One of them is by using learning methods that can make students active and fun. In addition to methods, teachers can use learning media to create interest in students to be more creative, active and innovative by using media as an intermediary in learning.

One of the goals of mathematics learning in schools is understanding concepts, explaining the interrelationships between concepts and applying mathematical concepts in solving mathematical problems that are interrelated with each other and related to scientific disciplines and daily life (Ministry of National Education, 2006). The ability to associate mathematics with between topics in mathematics, other disciplines, and everyday life is called mathematical connection ability. This is in accordance with the opinion of Ruspiani (Setiawan, 2009: 15) which states that mathematical connection ability is the ability of students to associate mathematical concepts with other fields of science (excluding mathematics). However, when in the field the results of the preliminary survey require that there are indicators of mathematical abilities that students have not maximally possessed, one of which is mathematical connection ability. This is the basis for conducting research and analyzing the causes of low mathematical connection skills (Forgive, 2015).

Aripin \& Purwasih (2017) that the abilities possessed by students affect their learning achievement. One of the mathematical abilities that students must have is mathematical connection skills. Students who have good mathematical connection skills are able to understand mathematical concepts in more depth. This is in accordance with the opinion of NCTM (2000: 64) if students have the ability to connect mathematical concepts mathematically, it can be said that students have a deeper understanding and can last longer. Students' understanding of mathematics will be very good, if students can associate

\section{Method}

The place of research was conducted at Negri 47 Bandung Middle School, the odd semester of the $2017 / 2018$ academic year. The method used in this study is descriptive qualitative which seeks to describe the analysis of mathematical connections and student self confidence. The subjects in this study were students of class IX F. The subjects were chosen by asking for the opinions of class teachers who understood the cognitive and affective conditions of students. The research phase is divided into three, namely planning, implementation and reporting. At the planning stage the researcher prepares a set of mathematical connection instruments including validated questions, answers and scoring worksheets, and prepares instruments for self confidence including questionnaire grids, questionnaire weights, and scoring. Data collection from the results of this study is a test of mathematical connection ability consisting of 5 essay questions and attitude scale questionnaire. Then at the implementation stage students are given a mathematical connection test, after which students fill out a self confidence questionnaire. At the report stage, the researcher processes the data obtained during the research and prepares the report. The main instruments in this study were description tests and attitude scale questionnaires. The test kits used to collect data in this study are 5 items about mathematical connections according to indicators. Questionnaire used to determine self confidence in students there are 10 negative statements and 10 positive statements. This attitude scale uses a modified Likert scale. To find out the mathematical connection ability of students, it is done by analyzing students' answers and compared with the actual answers. While the way to see students' self confidence is by looking at the weight of the questionnaire scoring that has been filled in by the students. To analyze the results of the student's self confidence questionnaire, the analysis phase was carried out including: tabulating the questionnaire answers from all students; calculate the percentage of student answers for each criterion; then To average

using the formula: $\bar{x}=\frac{\text { total }}{\text { banyak responden }}$ Whereas to find the percentage using the formula: $\%=\frac{X}{S M I} \times 100 \%$ to draw conclusions from the results of these percentages.

\section{Findings and Discussion}

This research was conducted on class IX students in semester 1 in 47 Bandung State Middle School 2017-2018 academic year. The number of students in the class is 31 people. The researcher tested 5 items about connection with the material Build Flat Side Space. After completion, students are given a questionnaire to measure affective abilities when learning in class, especially when working on the 
questions usually given by the teacher. The results of the posttest, students did not experience difficulties in connecting questions. Students have been able to guess the problem, and not hesitate to do it. So below, the results of posttest analysis of classmatic mathematical connection capabilities are presented in Table 1 .

Table 1. Percentage Score of Students' Mathematical Connection Skill

\begin{tabular}{|c|c|c|c|c|c|}
\hline \multirow[t]{2}{*}{ Statistical Data } & \multicolumn{5}{|c|}{ Mean Score of Each Items } \\
\hline & SMI & Item & $\mathrm{X}$ & $\%$ & X Total \\
\hline $\begin{array}{l}\text { Investigating the relationship of various concept and } \\
\text { procedure representation }\end{array}$ & 4 & 1 & 3,22 & $80,64 \%$ & \\
\hline Understanding the relationship among mathematics & 4 & 1 & 3,29 & $82,25 \%$ & 3,18 \\
\hline Understanding the same equivalence concepts representation & 4 & 1 & 3,22 & $80,64 \%$ & \\
\hline Implementing the relationship of mathematics topic in real life & 4 & 2 & 2,98 & $74,59 \%$ & \\
\hline
\end{tabular}

The table above shows the results obtained by students on the test about mathematical connection skills, students did not experience difficulties in working on the problem. The decomposition of the results of each indicator are: 1) Finding the relationship of various representations of concepts and procedures, obtaining the results of a percentage of $80.64 \%$, which means students can understand the concept of the problem to find relationships of various representations of concepts and procedures so that the results are as expected . 2) Understanding the relationship between mathematical concepts, obtaining $82.25 \%$ presentation results which means students can understand the relationship between mathematical concepts of the items in question. 3) Understanding representation is equivalent to the same concept, obtaining results of $80.64 \%$, which means students can work on problems in understanding equivalent representations of the same concept. 4) Applying the relationship of mathematical topics in real life, obtaining results of $74.59 \%$, which means students can apply the relationship of mathematical topics in real life to the problem. The overall average seen in Table 1 is 3.18 of 4.0. This shows significant results for connection capabilities.

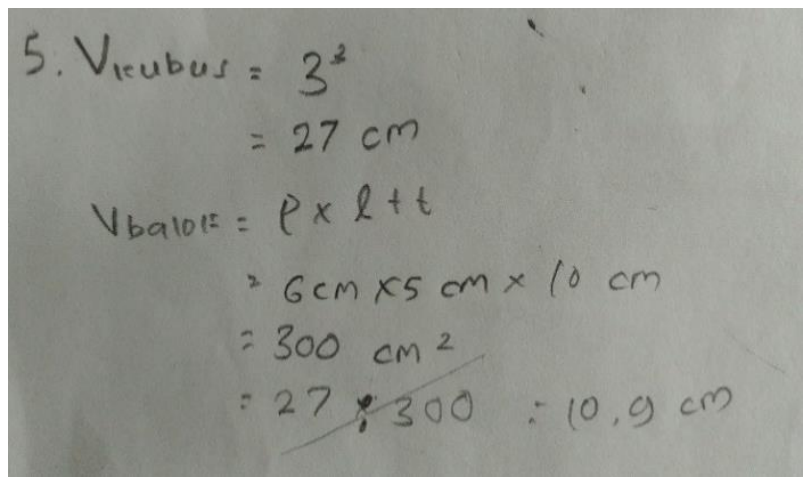

Picture 1. One of Students' Answers

In figure 1 above is one of the students' answers regarding the material of building a flat side space. From the picture, it can be seen that students have not been able to master the ideas and concepts of building space properly. In working on the problem students are still mistaken in determining the high volume of water that has been inserted into the object. The question has an indication of the relationship between mathematical concepts. This means that students still have a lack of understanding about the relation of one concept to another. Students have not been able to simplify and do multiplication. Even 
though multiplication surgery is a basic concept that must be understood by students at the elementary school level. Many factors cause students to be more familiar with the concepts, because what he knows is only one way. Some students accidentally asked why the student could not answer the number one question correctly because the students included students who were very interactive. The student gave an answer that multiplication operations cannot be done for tens and hundreds. These students have flaws in terms of the basic concept of multiplication. These students experience a miss concept from elementary school and an incomplete understanding so that the lack of understanding of a concept is left alone finally piling up and students do not understand the previous mathematical concepts.

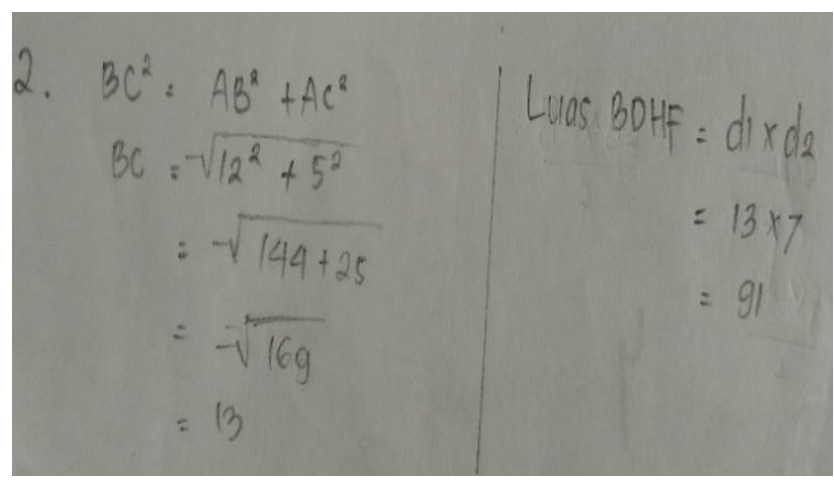

Picture 2. Example of Students' Answer

In Figure 2 above is one of the students' answers regarding diagonal plane material in the building space. From the picture it can be seen that students are able to calculate the diagonal plane correctly. Stages of students in working on the problem is in accordance with what is expected. See the answer above that students already understand the questions on the question. Students can understand how to determine $\mathrm{BC}$ values through the concepts of phytaghoras and rank. Students can do a count operation well so that they get a long value of $\mathrm{BC}=13$. This student is able to do the Phytaghoras concept applied in other concepts. Indicator connection capabilities understand the relationship between concepts students are able to apply. The student correctly determines the area of the BDHF area which is the diagonal plane in the building of the space correctly.

Based on interviews, students did not experience difficulties in determining the area and volume value of the building. But there are a number of students who have poor countdown operations. Students can apply the Pythagorean theorem correctly. The concept of volume error is caused by students not being able to multiply. Based on questionnaires, students like math because they provide challenges in answering questions. In addition, the results of the questionnaire that has been processed show that 1) Students have been able to make their own decisions in working on the problem 2) Students have the drive to excel so that they can create self-confidence 3) Students still need help from others to work on problems and students still feel anxious about the answer itself 4) Students feel free in determining strategies in solving problems that are different from others even though the results are the same. 5) Students already know their weaknesses and strengths. In the table below is a description of the results of the analysis of pretest self confidence data.

Table 2. Statistic Descriptive Pretest of Students' Learning Confidence

\begin{tabular}{llllll}
\hline Indicator & Items & Total & & & Category \\
\cline { 3 - 5 } & & Score & Mean & $\%$ & \\
$\begin{array}{l}\text { Believe in one's own abilities, } \\
\text { not worry }\end{array}$ & 4 & 351 & 2,83 & $56,70 \%$ & Sufficient \\
$\begin{array}{l}\text { Feel free, and responsibility for } \\
\text { his actions }\end{array}$ & 4 & 416 & 3,35 & $67,10 \%$ & Good \\
$\begin{array}{l}\text { Acting alone in making decisions } \\
\begin{array}{l}\text { Dare to express opinions and } \\
\text { have an urge to excel }\end{array}\end{array}$ & 4 & 405 & 3,23 & $65,00 \%$ & Good \\
& & 429 & 3,46 & $69,20 \%$ & Good \\
\hline
\end{tabular}




\begin{tabular}{|c|c|c|c|c|c|}
\hline $\begin{array}{l}\text { Get to know the strengths and } \\
\text { weaknesses of yourself }\end{array}$ & 4 & 413 & 3,33 & $66,70 \%$ & Good \\
\hline
\end{tabular}

From the table above, the results obtained in the Self Confidence questionnaire of students have enough confidence. As for the breakdown of the masses of each indicator, the first indicator gets $56.70 \%$ which indicates that students are good enough to believe in their own abilities, and not anxious during learning in grade 2) On the second to 5th indicators in the learning results $67.10 \%, 69.20 \%, 66.70 \%$ indicate that students are able to meet learning needs where students can prepare their own learning, feel free and responsible for their actions, act in making decisions, dare to express their opinions and have the urge to excel, and recognize their own strengths and weaknesses. The results of interviews with some students that they lack confidence if they want to express their opinions or ask questions about material that is not understood. This is because they are afraid of how to express it when asking. In addition, the motivation that arises in each student influences the learning objectives. This is in line with Pujiono (2017) that motivation is seen as a process characterized by a reaction to achieve a goal. These findings were obtained in this study, that a strong motivation to try to solve mathematical problems faced would be contagious to their peers. Each other gives enthusiasm and motivation in learning will have an impact on the student's own achievement.

\section{Conclusion and Suggestions}

The results of the research on the mathematical connection ability of students at 47 Bandung Middle School can be concluded that overall the students' mathematical connection ability is good. But there are difficulties experienced by students, namely how to apply the relationship of mathematical topics in real life. In this case, students are still having difficulty understanding mathematical concepts in terms of the ability of connections that have been given. While in self confidence students have enough confidence in their own abilities and do not feel anxious in solving the questions that have been given. Of the 31 students only 1 person can solve the problem well. Students do not understand the problem with the problem experienced by 4 people. Students cannot do the multiplication correctly in the calculation of the volume experienced by 14 people. There are 21 students who do not have process skills in determining dioagonal area. Students cannot conclude the answer in determining the volume of beams and cubes as many as 30 people.

\section{References}

Ajay, K., (2016), Effect of Student Teams Achievemnt Division (STAD) method on problem solving ability in relation to Critical Thinking, International Journal of Advanced Research and Development, Vol. 1, Page No. 26-30

Aripin, U.,\& Purwasih, R. (2017). Penerapan Pembelajaran Berbasis Alternative Solutions Worksheet Untuk Meningkatkan Kemampuan Berpikir Kreatif. AKSIOMA: Jurnal Program Studi Pendidikan Matematika, 6(2), 225-233.

Depdiknas (2006). Kurikulum Tingkat Satuan Pendidikan. Jakarta: Depdiknas.

Fitriani, F.(2015). Hubungan Antara Kemampuan Pemecahan Masalah Matematis Denganself Confidencesiswa Smp Yangmenggunakan Pendekatan Pendidikan Matematikarealistik. Jurnal Euclid, 2(2), 341-351.

Giarti, Sri. 2014. Peningkatan Keterampilan Proses Pemecahan Masalah dan Hasil Belajar Matematika Menggunakan Model PBL Terintegrasi Penilaian Autentik pada Siswa Kelas VI SDN 2 Bengle Wonosegoro. Scholaria. 4 (3), 13-27.

Hendriana, H,. Rohaeti, E E,. \& Sumarmo, U,. (2017). Hard Skill Soft Skill Matematik Siswa. Bandung; Refika Aditama.

Muhsetyo Gatot, dkk. 2009. Pembelajaran Matematika SD. Jakarta: Universitas Terbuka. 
Maarif, H., \& Wahyudi, W. (2015). Eksperimentasi Problem Based Learning dan CIRC dalam Menyelesaikan Soal Cerita Matematika Siswa Kelas 5 SD. Scholaria: Jurnal Pendidikan dan Kebudayaan, 5(2), 97-115.

NCTM (2000). Principle and Standards for School Mathematics. Reston, VA: NCTM.

Purwasih, R. (2015). Peningkatan Kemampuan Pemahaman Matematis dan Self Confidence Siswa MTS di Kota Cimahi Melalui Model Pembelajaran Inkuiri Terbimbing. Didaktik, 9(1),16-25.

Pujiono, R. (2017). Penerapan Model Pembelajaran Kooperatif Tipe Student Team Achievement Divisions (STAD) Untuk Meningkatkan Motivasi Dan Hasil Belajar Ipa Siswa Kelas V B SDN 047 Tarakan. Journal of Education Research and Evaluation. 1 (4), 198-203.

Rattanatumma, T., (2016), Assessing the Effectiveness of STAD Model and Problem Based Learning in Mathematics Learning Achievement and Problem Solving Ability, Journal of Education and Practice, Vol. 7, No. 12

Setiawan, A. 2009. Inplementasi Model Pembelajaran Conceptual Understanding Procedures (CUPS) sebagai Upaya untuk Meningkatkan Kemampuan Koneksi Matematika siswa. Skripsi Jurusan Pendidikan Matematika FPMIPA UPI : Tidak Diterbitkan.

Siswanto, R., (2014), Peningkatan Kemampuan Penalaran Dan Koneksi Matematis Melalui Penerapan Model Pembelajaran Kooperatif Tipe STAD Berbantuan Geogebra (Studi Eksperimen Di SMAN 1 Cikulur Kabupaten Lebak Provinsi Banten), Jurnal Pendidikan dan Keguruan, vol 1, No.1

Supraptinah, U., Budiyono, B., \& Subanti, S. (2015). Eksperimentasi Model Pembelajaran Discovery Learning, Problem Based Learning, Dan Think-Talk-Write Dengan Pendekatan Saintifik Terhadap Kemampuan Pemecahan Masalah Matematika Ditinjau Dari Kemandirian Belajar Siswa. Jurnal Pembelajaran Matematika, 3(10).

Uno,H. 2007. Model Pembelajaran Menciptakan Proses Belajar Mengajar Yang Kreatif Dan Efektif. Jakarta: Bumi Aksara.

Wahyudi, W., \& Siswanti, M. C. (2015). Pengaruh Pendekatan Saintifik Melalui Model Discovery Learning dengan Permainan Terhadap Hasil Belajar Matematika Siswa Kelas 5 SD. Scholaria: Jurnal Pendidikan dan Kebudayaan, 5(3), 23 